\title{
FEDERAL TAXATION: SHORT TERM TRUST INCOME USED TO DISGHARGE IMPLIED CONTRACTUAL OBLIGATIONS HELD TAXABLE TO THE GRANTOR
}

\author{
$\mathrm{T}$ \\ HE USE OF a short term" or "Clifford" trust ${ }^{2}$ as a device for mini- \\ mizing income taxes has been consistently limited by the legal obli-
}

I See INT. REv. CoDE of 1954, $\S \S 671-78$. As a general rule, the grantor of a trust is not taxed on the income earned by the trust corpus unless he is considered the "substantial owner." In $\$ 673(a)$, however, it is provided that a reversionary interest in either the corpus or income is not "substantial ownership" for tax purposes if the reversion will not take effect in possession or enjoyment within ten years of the transfer of the corpus to the trust; furthermore, under $\$ 677$ (a), income during the ten year period may not be accumulated for distribution to the grantor. Transfers under $\$ 673$, therefore, are called "short term" trusts and constitute a popular device in family tax arrangements.

Many limitations and exceptions are imposed upon the basic structure provided in $\$ 673$ (a). Exceptions to the ten year rule are stated in $\$ \S 673$ (b)-(c). Neither the grantor nor a nonadverse party may retain the power to control the bencficial enjoyment of the trust corpus or income under $\$ 674$ (a); exceptions to this qualification are enumerated in $\$ \$ 674$ (b)-(d). Restrictions on retained administrative powers and the power to revoke the trust are set forth in $\$ \$ 675-76$.

For purposes of this casenote, however, the important restriction is contained in \$ 677. If the income of the trust may, without the consent of an adverse party, be distributed to the grantor, held or accumulated for future distribution to the grantor, or be applied to certain life insurance premiums on the life of the grantor, then such income which may be so applied or distributed is taxable to the grantor. The courts and the Treasury Department have said that income applied to the discharge of a legal obligation of the grantor is deemed to have been distributed to the grantor for purposes of $\S 677$ (a). See, e.g., Douglas v. Willcuts, 296 U.S. 1 (1985). However, where the trustee or person other than the grantor has a discretionary power to apply income in the satisfaction of the grantor's legal obligation of support, it is taxable to the grantor under $\$ 677$ (b) only to the extent it has in fact been so applied.

See generally Alexander, The Short Term Trust, 31 Mrss. L.J. 263 (1960); Colgan, The Short Term Trust, Trust Bull., Sept. 1956, p. 3; Durkin, Short Term Reversionary Trusts, 20 OHro ST. L.J. 80 (1959); Foosaner, Short Term Trusts Can Now De Used to Lower Tax Liability, 4 J. TAxation 222 (1956); Grotheer, Short Term Trusts and Their Pitfalls, Trust Bull., Feb. 1959, p. 27; MacNeil, Short Term Trusts-Their Uses and Abuses, 101 Trusts \& Estates 16 (1962); Schuyler, Short Term Trusts-A Positive Approach to a Law Full of Negatives, Trust Bull., Feb. 1957, p. 20; Yohlin, The Short Term Trust-A Respectable Tax Savings Device, 14 TAx L. REv. 109 (1958).

${ }^{2}$ Helvering v. Clifford, 309 U.S. 331 (1940). This was the first case in which the Supreme Court held that short term trust income would be taxed to the grantor if lie retained substantial ownership in the trust. In an attempt to refine the Clifford case by establishing specific elements of control, the Treasury promulgated the "Clifford Regulations." Treas. Reg. 118, § 39.22 (a)-21 (1944); Treas. Reg. 111, § 29.22 (a)-21 (1944), added by T.D. 5488, 1946-1 CUM. Bul.. 19, as amended, T.D. 5567, 1947-2 CuMr. BuLL. 9. These regulations constitute the basis for the present code sections dealing with short term trusts. See note I supra.

See generally Alexandre, $A$ Case Method Reslatement of the New Clifford Regula. tions, 3 TAx L. REv. 189 (1947); Atlas, The Clifford Regulations: Genesis of a Concept, 25 TexAs L. REv. 373 (1947); Eisenstein, The Clifford Regulations and the Heavenly City of Legislative Intention, 2 TAX L. REv. 327 (1947); Guterman, The New Clifford 
gation doctrine. ${ }^{3}$ Under this concept short term trust income has been held taxable to the grantor when applied to discharge either his express contractual obligations or duties imposed by law. ${ }^{4}$ In Morrill v. United States, ${ }^{5}$ the scope of the legal obligation doctrine was extended for the first time to include the use of short term trust income to discharge implied contractual obligations.

In Morrill the grantor established short term trusts for each of his four children, giving the trustees discretionary power to pay college and private school fees from trust income. ${ }^{\circ}$ Five schools subsequently attended by the children sent their bills to the grantor, who in turn passed them on to the trustees for payment. ${ }^{7}$ The grantor conceded that by signing agreements with two of the schools he had expressly obligated himself to pay all expenses incurred by his children. ${ }^{8}$ But he argned that in the absence of an express contractual obligation or legal duty of support, he could not be taxed on trust income paid to the other three schools. The court, however, found that the grantor had impliedly obligated himself by his conduct to pay the room and tuition charges. ${ }^{2}$ It held that these implied contracts were legal obligations, and that trust income used to discharge contractual obligations, either express or implied, was therefore taxable as income to the grantor..$^{10}$

The short term trust permits a high income taxpayer to transfer income-producing property to a trust for a minimum period of

Regulations, I TAX L. REv. 379 (1946); Magill, What Shall Be Done with the Clifford Case, 45 Colum. L. REv. 111 (1945); Pavenstedt, The Treasury Legislates: The Distortion of the Clifford Rule, 2 TAx L. REv. 7 (1946); Seidman, The Income Tax Regulations of Trusts, 24 TAXEs 549 (1946); Smith, How New Regulations Affect the Clifford Case, 24 TAXes 624 (1946).

${ }^{3}$ Treas. Reg. $\S 1.677$ (a)-1 (d) (1956). See generally 6 Mertens, Federal Income TAXATION $\$ 37.47$ (1957) [hereinafter cited as Mertens].

Id. $\$ 37.09$.

228 F. Supp. 734 (D. Me. 1964).

- The trust agreement provided for the accumulation of income to be paid the children at age twenty-one provided, however, that income could be applied at the discretion of the trustee to pay college and private school expenses. Brief for Defendant, p. 4.

" Morrill would send the bills to the trustees with his personal check for expenses, exclusive of room and tuition, and a request that trust income be used to pay the room and tution charges. The trustee would draw a check on the trust income and send it with Morrill's check to the schools. 228 F. Supp. at 735.

${ }^{8} I d$. at 736; see $i d$. at 735 n.1.

Id. at 737; see 3 Corbin, Contracts $\$ 566$ (1960); Restatement, Contracts $\$ 72$ (1932).

${ }^{20} 228$ F. Supp. at 737 . 
time.11 The advantages of this device are the temporary removal of income from the grantor's high tax bracket, application of the income to the benefit of a person in a lower bracket, and the return of the corpus to the grantor after a ten year period. The trust income, however, may be taxed to the grantor if he has retained control of or received benefit from the trust, thereby rendering the grantor a "substantial owner."12 Thus, under section 677 (a) of the 1954 Code, ${ }^{13}$ the grantor is treated as the owner of any portion of a trust whose income may be "distributed to the grantor"14 without the consent of an adverse party. ${ }^{15}$ The courts and the Treasury Regulations $^{16}$ have maintained that the application of trust income to discharge a grantor's "legal obligation" is to be treated as such a distribution of income. ${ }^{17}$ This is consistent with the concept of "income" evolved under other sections of the Internal Revenue Code. ${ }^{18}$ The

11 See note 1 supra.

12 Helvering v. Clifford, 309 U.S. 331 (1940). See notes 1-2 supra.

18 "The grantor sball be treated as the owner of any portion of a trust . . . whose income without the approval or consent of any adverse party is, or, in the discretion of the grantor or a nonadverse party, or both, may be-

(1) distributed to the grantor; . . ." INT. REv. Cone of 1954, § 677 (a).

14 Regardless of whether trust income is distributed to the grantor pursuant to a mandatory provision or pursuant to the discretion of a nonadverse party, it is no longer of any consequence to the tax liability of the grantor under $\S 677$ (a) if the trust income is actually used to discharge his legal obligation. Furthermore, in a discretionary trust the possibility that short term trust income may be distributed to the grantor will also result in tax liability under $\$ 677$ (a). The section is concerned not only with the actual distribution, but with what might be done with the trust income. Rollins v. Helvering, 92 F.2d 390 (8th Cir.), cert. denied, 302 U.S. 763 (1937). See Helvering v. Evans, 126 F.2d 270 (3d Cir. 1942); Altmaier v. Commissioner, 116 F.2d 162 (6th Cir. 1940), cert. denied, 312 U.S. 706 (1941). An exception to this latter rule is found in $\S 677$ (b) of the code to the extent that if the trust provides for a discretionary distribution of income to discharge the grantor's legal obligation of support, only that amount of trust income actually applied will be taxable to him. See note 17 infra.

${ }^{15}$ An adverse party is "any person having a substantial beneficial interest in the trust which would be adversely affected by the exercise or nonexercise of the power which he possesses respecting the trust." INT. REv. CODE OF 1954, § 672.

${ }^{10}$ See note 3 supra.

${ }^{17}$ Since the 1989 Code contained no special provision for the taxation of slort term trusts, the Supreme Court used various sections to determine the tax liability of the grantor. The Court relied on $\S 22$ (a) (predecessor of $\S 61$ (a) of the 1954 code), defining gross income, to tax the grantor when income was required by the trust agreement to be. used in the satisfaction of the legal obligations of the grantor. Douglas v. Willcuts, 296 U.S. I (1935). However, the Court applied $\S 167$ of the 1939 Code (similar in language to $\$ 677$ (a) of the 1954 Code) to tax short term trust income to the grantor when he or a nonadverse party retained the discretionary power to apply that income to discharge the grantor's legal obligations. Helvering v. Stuart, 317 U.S. 154 (1942).

${ }^{18}$ See, e.g., Old Colony Trust Co. v. Commissioner, 279 U.S. 716 (1929) (payment of employee's income taxes constitutes income to the employee); Canton v. United 
satisfaction of a legal obligation by a third party relieves the taxpayer of a primary liability for payment, and hence constitutes measurable economic benefit. ${ }^{19}$

Until the decision in the instant case, courts have applied the legal obligation doctrine only to situations in which trust income was used to satisfy an obligation imposed upon the grantor by law or express contract. ${ }^{20}$ Thus, the grantor has been taxed where short term trust income was used ${ }^{21}$ to discharge a debt of the grantor, ${ }^{22}$ to pay gift taxes on the trust transfer, ${ }^{23}$ to pay income or property taxes, ${ }^{24}$ to discharge encumbrances on real estate, ${ }^{25}$ to meet alimony payments, $^{26}$ or to discharge the grantor's duty of support. ${ }^{27}$

In determining whether a duty of support was a legal obligation the courts have looked to the law of the local jurisdiction, ${ }^{28}$ resulting in a lack of uniformity among the decisions. ${ }^{20}$ The question of whether a college education is a necessary element of support reflects this conflict. ${ }^{30}$ The majority of cases have held that a college

States, 226 F.2d 313 (8th Cir.), cert. denied, 350 U.S. 965 (1955) (cancellation of loan made to taxpayer by his brother resulted in taxable income).

${ }^{20}$ See Treas. Reg. $\$ 1.662$ (a)-4 (1956), which provides that trust income used to support a beneficiary whom a third person has a primary legal obligation to support is taxable to such third person.

so See 6 MERTENS $\$ 37.09$, at 36 n.10 (1957).

${ }^{21}$ See note 14 supra.

${ }^{29}$ Helvering v. Blumenthal, 296 U.S. 552, reversing 76 F.2d 507 (2d Cir. 1935); James L. Knight, 39 B.T.A. 436 (1939); Rev. Rul. 54-516, 1954-2 CuM. BuLx. 54.

${ }^{38}$ Sheaffer's Estate v. Commissioner, 313 F.2d 738 (8th Cir.), cert. denied, 375 U.S. 818 (1963); Staley v. Commissioner, 136 F.2d 368 (5th Cir.), cert. denied, 320 U.S. 786 (1943); Rev. Rul. 57-564, 1957-2 CuM. BuL.. 326.

24 John Koehrer, 14 P-H Tax Ct. Mem. 235 (1945); cf. Old Colony Trust Co. v. Commissioner, 279 U.S. 716 (1929).

${ }^{25}$ See Rev. Rul. 54-516, 1954-2 CuM. BuLL. 54 (grantor remained liable on mortgage on real estate transferred to trust); $c f$. Rev. Rul. 55-286, 1955-1 CuM. BuL. 75.

${ }^{20}$ Helvering v. Fitch, 309 U.S. 149 (1940).

${ }^{27}$ Helvering v. Stuart, 317 U.S. 154 (1942); Helvering v. Schweitzer, 296 U.S. 551 (1935), reversing 75 F.2d 702 (7th Cir. 1935); Estate of Hamiel v. Commissioner, 258 F.2d 787 (6th Cir. 1958); Mairs v. Reynolds, 120 F.2d 857 (8th Cir. 1941). See also note 14 supra.

${ }^{28}$ See Mairs v. Reynolds, 120 F.2d 857 (8th Cir. 1941); Commissioner v. Tuttle, 89 F.2d 112 (6th Cir. 1937). Compare Annot., 1 A.L.R.2d 910, 914 (I948) (no parental responsibility to children of majority age).

${ }_{20}$ Compare Parker v. Commissioner, 166 F.2d 364 (9th Cir. 1948), with Commissioner v. Tuttle, 89 F.2d 112 (6th Cir. 1937). The test for legally required support has for the most part been a practical one-was income applied to the extent the grantor would have provided notwithstanding the existence of the trust and its income. See Hill v. Commissioner, 88 F.2d 941 (8th Cir. 1937); Alfred C. Berolzheimer, 40 B.T.A. 645, rev'd on other grounds, 116 F.2d 628 (2d Cir. 1940).

${ }^{30}$ Compare Titus v. Titus, 311 Mich. 434, 18 N.W.2d 883 (1945), with Hachat v. Hachat, 117 Ind. App. 294, 71 N.E.2d 927 (1947). 
education is within the duty of support, ${ }^{31}$ and the standard usually applied has been whether the parents are financially able and the child capable of college level work.

The court in Morrill, however, did not reach the issue of whether the grantor-parent was obligated under Maine law to provide for the college education of his children. ${ }^{32}$ Instead, it found an implied contractual obligation to be within the scope of the legal obligation doctrine. ${ }^{33}$ It is possible that the court in Morrill selected the implied contract theory to avoid the uncertainty in Maine law regarding college education as an element of support. ${ }^{34}$

Nevertheless, the Morrill decision may be criticized on the theory that an additional ground for asserting tax liability should not have been invoked unless existing bases for imposing liability have been exhausted. ${ }^{35}$ However, the implied contractual obligation theory of

s1 Hale v. Hale, 55 Cal. App. 2d 879, 132 P.2d 67 (Dist. Ct. App. 1942); Maitzen v. Maitzen, 24 Ill. App. 2d 32, 163 N.E.2d 840 (1959); Hart v. Hart, 239 Iowa 142, 30 N.W.2d 748 (1948); Allison v. Allison, I88 Kan. 593, 363 P.2d 795 (1961); Johnson v. Johnson, 346 Mich. 418, 78 N.W.2d 216 (1956); Pass v. Pass, 238 Miss. 449, 118 So. 2d 769 (1959); Refer v. Refer, 102 Mont. 121, 56 P.2d 750 (1936); Lund v. Lund, 96 N.H. 283, 74 A.2d 557 (1950); Cohen v. Cohen, 6 N.J. Super. 26, 69 A.2d 752 (Super. Ct., App. Div. 1949) (dictum); Mitchell v. Mitchell, 170 Ohio St. 507, 166 N.E.2d 396 (1960); Stoner v. Weiss, 96 Okla. 285, 222 Pac. 547 (1924); Jackman v. Short, 165 Ore. 626, 109 P.2d 860 (194I); Atchley v. Atchley 29 Tenn. App. 124, 194 S.W.2d 252 (1945); Golay v. Golay, 35 Wash. 122, 210 P.2d 1022 (1949) (dictum); Peck v. Peck, 271 Wis. 466, 76 N.W.2d 316 (1956); cf. Rufner v. Rufner, 131 N.J. Eq. 193, 24 A.2d 180 (Ct. Err. \& App. 1942). Contra, Worthington v. Worthington, 207 Ark. 185, 179 S.W.2d 648 (1944); Hachat v. Hachat, 117 Ind. App. 294, 71 N.E.2d 927 (1947); Clark v. Graves, 282 S.W.2d I46 (Ky. 1955) (college education not part of required support but ordered father to continue payments while child attended college on scholarship); Middlebury College v. Chandler, 16 Vt. 683 (1814). Compare Herbert v. Herbert, 198 Misc. 515, 98 N.Y.S.2d 846 (Dom. Rel. Ct. 1950), with Samson v. Schoen, 204 Misc. 603, 121 N.Y.S.2d 489 (Dom. Rel. Ct. 1953).

32 The point was, however, argued by both parties in their briefs.

33228 F. Supp. at 737 .

st It would appear from a decision of the Maine supreme court that certain requirements must be met before the court would consider college or higher education to be within the statutory requirements of support. In a leading case the court held that an order providing additional payment by the father to the mother for the minor child's musical training was within the purpose and intention of the Maine support statute. The court considered that such additional payments were warranted by the child's natural talent, the necessity of providing a vocation, conformance with her station in life, the father's financial ability, and the standard of living established by the father before the divorce. Luques v. Luques, $127 \mathrm{Mc}$. 356, 143 Atl. 263 (1928).

Using the Luques decision as a basis, a Maine .court would probably look with favor upon the theory that a parent, if financially able and the child capable, would be obligated under the law of Maine to provide a college education for that child. See note 31 supra and accompanying text.

35 In a similar factual situation, another court has intimated the existence of implied contractual obligations with colleges, but disregarded them by basing its 
liability is not a novel interpretation of the law, but merely a logical extension of the legal obligation doctrine. Although the term legal obligation has not been defined, it is reasonable to assume that it contemplates all obligations of the grantor which would be enforceable in a court of law, whether they be the product of a legally imposed duty, or a contract, express or implied.36 To allow a grantor to escape tax liability merely because he has bound himself by his conduct instead of words would be contrary to the meaning and purpose of the legal obligation doctrine. ${ }^{37}$

The Morrill decision has special significance in cases where the grantor is bound neither by an express contract nor by a duty imposed by law. As a general rule of contract law, an express contract is created by oral or written manifestations of assent, whereas an implied contract is the result of mutual promises implied from the conduct of the parties. ${ }^{38}$ This necessitates a careful analysis of the surrounding circumstances in each case, including the history of prior dealings and the expectations of the parties. However, various problems of interpretation may result from imposing tax liability through state laws of implied contract. ${ }^{39}$ Suppose, for example, that a grantor establishes a short term trust for the benefit of his elderly parents to whom no duty of support is owed. ${ }^{40}$ If the parent's doctor sends his bill for medical services to the son instead of the invalid parent, payment of the bill with trust income might be held taxable to the grantor-son unless he had advised the doctor that future bills should be directed to the trustee. If, however, the grantor-son is in fact the trustee as well, is the bill sent to him in his capacity as a trustee or as grantor? Suppose further that the trust was created after the grantor has already made several payments. Can the obligation as to future bills be shifted by advising the doctor of the existence of the trust?

decision upon the duty of a parent under Minnesota law to provide for the college education of his children. Mairs v. Reynolds, 120 F.2d 857 (8th Cir. 1941).

${ }^{30}$ But see note 43 infra.

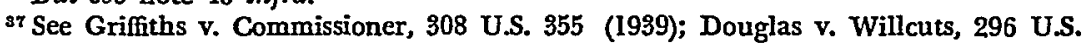
1 (1935); Estate of Hamiel v. Commissioner, 253 F.2d 787 (6th Cir. 1958); Hopkins v. Commissioner, 144 F.2d 683 (6th Cir. 1944).

sa 1 Corbin, ConTracts $\$ 18$ (1963); Simpson, Contracts $\S 5$ (1954); 1 Whiliston, CoNTRAGTS $\$ 3$ (3d ed. 1957).

${ }^{80}$ Regardless of which theory is used to invoke the legal obligation doctrine, the decision will be predicated upon state law. See, e.g., Mairs v. Reynolds, 120 F.2d 857 (8th Cir. 1941); Commissioner v. Tuttle, 89 F.2d 112 (6th Cir. 1937).

${ }^{\circ 0}$ For other typical uses of short term trusts see Woodward, The Short Term Trust: A Useful Device for Tax Savings in Many Situations, $8 \mathrm{~J}$. TAxATION 242 (1958). 
Another problem is presented in the case of a grantor-father who accompanies his adult son to purchase a sailboat and tacitly indicates his approval of the youth's selection. Has the grantor impliedly obligated himself to pay the installments by not advising the salesman of the existence of the trust? Or suppose the grantor-father's minor daughter attended a finishing school and he has paid previous bills to fulfill his legal obligation to educate a minor. Does the previous course of conduct impliedly obligate him to continue paying the fees once the daughter has reached her majority?

The grantor could avoid the risk of taxation in the aforementioned hypotheticals by requesting the third party to look to the trust for payment of future debts. ${ }^{41}$ As a practical matter, though, the third party may not be willing to accept this arrangement, particularly if the distribution of trust income is left to the discretion of the trustee. In this event, the third party might accede to the request if the grantor agreed to act as a guarantor. Although payment by use of trust funds would discharge the grantor's secondary liability, such payment should not constitute "income" to the grantor-guarantor. ${ }^{42}$ His obligation to pay does not mature into a primary legal liability until the principal debtor has defaulted. Nevertheless, the grantor would be well advised to assume only the posture of a grantor rather than a surety. ${ }^{43}$

Application of the legal obligation doctrine may be precluded by careful drafting of the trust agreement. If the beneficiary is

41 The court in Morrill relied heavily on the fact that the grantor had consented to the colleges' policy of sending bills to him and not to the trust. Sce 228 F. Supp. at 737.

12 The issue has never been decided by tbe courts. The failure to prosecute such cases may indicate the acquiescence of the Internal Revenue Service.

${ }^{4} \mathrm{~A}$ guarantor promises to account for the payment of a debt in the cvent the initial debtor fails to meet his obligation. Thus, satisfaction of a debt by use of trust income would not fulfill a legal obligation of the grantor-guarantor, for he would not become liable until the initial debtor (the trust) defaults.

The surety, on the other hand, is primarily liable from the onset, giving the creditor an option of collecting from either the surety or the initial debtor. From a conceptual point of view, therefore, it might be argued that satisfaction of a legal obhigation of the trust by use of trust income also discharges a primary legal obligation of the grantor-surety. However, no case has ever held the satisfaction of a legal obligation by the principal debtor to be taxable to the surety under the legal obligation doctrine, presumably because the surety is entitled to reimbursement from the initial debtor. That is, as long as the debtor-trust remains financially capable of payment, the surety will not bear the ultimate cost and responsibility of satisfying the debt.

The same rule of reimbursement applies to a guarantor, and it may be argued that default by the debtor-trust should not render subsequent payment by the trust taxable income to the grantor-guarantor despite the fact his liability has matured into a primary obligation. See SIMPSON, SURETYSHIP $\S \S 1-14$ (1950). 
given an unrestricted use of trust income, one thousand dollars a year may be distributed free of any tax. ${ }^{44}$ The use of this income by the beneficiary to pay college fees, or installments on a sailboat is not taxable to the grantor under section 677 (a). ${ }^{45}$ Although this avoids the problem inherent in short term trusts, the grantor might be taxed under the concept of "income" expressed in section 61 (a).46

As a final consideration, the impact of the Morrill decision may be diminished by the difficulty the Internal Revenue Service will encounter in detecting the existence of implied contracts. Aside from the bare recording of payment in the trustee's records, the Service might not be able to discover any other clue indicating the formation of an implied contractual obligation.

The Morrill case, therefore, adds another obstacle which the grantor of a short term trust must overcome in providing for the distribution of trust income. Although the decision is admittedly consistent with the theory of discharging a legal obligation, the desirability of creating another pitfall may be questioned in light of the problems inherent in interpreting state laws regarding implied contracts, the ease of avoidance by careful and well advised grantors, and the difficulty of discovering implied contractual obligations.

* By establishing a short term trust which would result in $\$ 1,000$ a year in income of which at least $\$ 100$ is derived from stock dividends, no taxes would need be paid under the 1964 amendments to the Code. INT. REv. CoDE OF 1954, $\S 116$ (a), as amended by Revenue Act of 1964, $\$ 201,78$ Stat. 19 (1964). With a trust income of $\$ 1,000$ less the increased stock dividend deduction of $\$ 100$, less the minimum standard deduction of $\$ 300$, less the individual's personal exemption of $\$ 600$, there would be no taxable income. See 4 P-H 1964 FED. TAXEs $₫ 32340$.

"Section 677 (a) does not reach the income payable to a beneficiary without restriction as to its use, though the beneficiary may thereafter apply it voluntarily to the benefit of the grantor. Lura H. Morgan, 2 T.C. 510 (1943), acq., 1944 CuM. BuLd. 20. The beneficiary's use of trust income to the benefit of the grantor would not be taxable to the grantor under $\S 677$ (a), because under $\S 672$ a beneficiary is considered an adverse party as to that income in which he has a substantial beneficial interest. Treas. Reg. $\$ 1.672$ (a)-1 (1956). See note 14 supra.

'INT. REv. CoDE of 1954, $\$ 61$ (a). See cases cited note 18 supra, dealing with $\S 61$ (a) treatment of satisfaction by third parties of obligations imposed upon the taxpayer by law or express contract. 